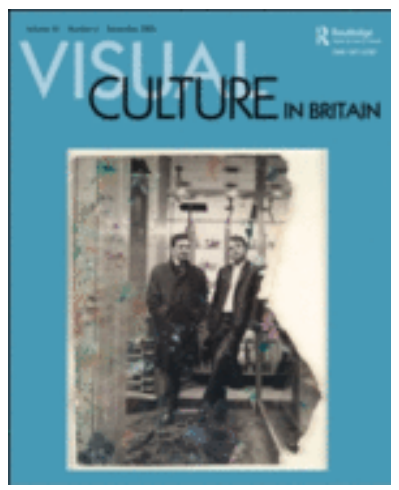

\title{
Picturing Resistance and Resilience: South Asian Identities in the work of Chila Kumari Burman
}

\begin{tabular}{|r|l|}
\hline Journal: & Visual Culture in Britain \\
\hline Manuscript ID & RVCB-2017-0024.R2 \\
\hline Manuscript Type: & Original Paper \\
\hline Keywords: & South Asia, Migration, Passports, Feminism, British art \\
\hline \multicolumn{2}{|l}{} \\
\end{tabular}

\section{SCHOLARONE Manuscripts}




\section{Picturing Resistance and Resilience: South Asian Identities in the work of Chila Kumari Burman}

\section{Introduction}
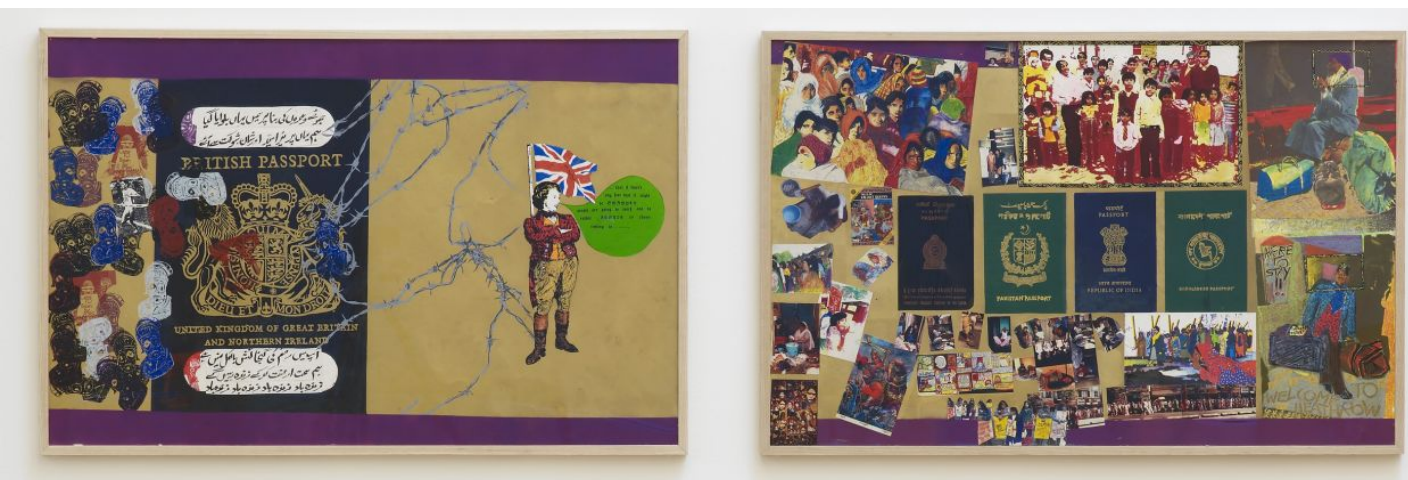

Fig.1, Chila Kumari Burman, Convenience, Not Love, 1986-7, colour silkscreen and laserjet print, with collage, private collection. Installation image: Nottingham Contemporary, 2017, Courtesy the Artist.

Although sharing a similar colour pallet, the two parts of Chila Kumari Burman's diptych Convenience, Not Love, 1986-7, are compositionally different (fig.1). The left-hand panel is divided into two parts, and contains an old-style navy-blue British passport adjacent to the figure of then Prime Minister Margaret Thatcher standing on a golden ground in front of a Union flag. Contrasting that relative iconographic sparsity, the right-hand panel is visually cacophonous, with a mass of collaged imagery presenting historic and contemporaneous South Asian figures, circulating around a centrally positioned row of passports from Sri Lanka, Pakistan, India and Bangladesh. Utilising the diptych format as a way of establishing a visual conversation between two opposing points of view, Convenience, Not Love may be understood as an engaging and dynamic artwork that synthesises a kaleidoscope of imagery in order to give not only an account of South Asian experiences of migration to Britain since the 1950s and British political objections to that migration, but also relay the ways in which South Asian women, in particular, have endured and withstood prejudice and discrimination. 
Chila Kumari Burman is perhaps best known for her unabashed and uncompromising series of self-portraits initiated in the early 1990 s, collectively titled, Autoportraits. Despite the widespread publication of these Autoportraits, Sophie Orlando has argued that they have, in the main, resisted critical scrutiny. ${ }^{1}$ Instead, these artworks have generally been discussed in terms of their "kitsch and cheerful luridity", ${ }^{2}$ and utilisation of a hyper-vibrant colour-pallet, reminiscent of both Andy Warhol's Pop celebrity portraits and the Bollywood film industry. Indeed, it has been perhaps too easy to identify much of Burman's work as superficial or disposable pop because of its visual excess: her application of all-over decoration, use of popular culture, and the brightness of her colour tones. However, undertaking a close reading of Convenience, Not Love - its iconography, artistic technique, and the historical and contemporaneous socio-political contexts in which it was made - this paper will argue that Burman's diptych signals her myriad concerns regarding the status of the South Asian diaspora and their lived experience in Britain, and in particular draws attention to the complexity and multi-faceted natures of female British Asian identities. I will suggest that these issues were further developed in two distinct bodies of work: firstly, a print series that utilised archival family photographs, which directly addressed her parental experience of migration; and secondly, her Autoportraits. It is my contention here that Burman's highly nuanced engagement with Black feminist issues, as evinced in Convenience, Not Love, evolved into a dissenting "radical narcissism", ${ }^{3}$ that infuses her later Autoportraits.

Trained as a printmaker first at Leeds Polytechnic, 1976-79, and then as a postgraduate at Slade School of Art, London, 1980-82, Burman was a pioneering visual artist actively working to rectify the orientalist stereotypes pinned to South Asian identities in Britain. In 1992, artists-curators Mumtaz Karimjee and Amina Patel, noted that "In the early eighties there was very little within the visual arts that explored the diversity of South Asian women's experiences in Britain". ${ }^{4}$ Indeed, historic and contemporary representations of the female-self were limited to images of servitude, epitomised by works such as Joshua Reynolds' George Clive and his Family with an Indian Servant Girl, 1765 (Gemäldegalerie, Berlin). As this paper will demonstrate, Burman actively challenged not only those colonial stereotypes of servitude and docility, but also the white feminist ideology that, as Hazel V. Carby argued, presented “Asian women as being in need of liberation". 5 Burman's 
commitment to active Black sisterhood may be witnessed in her willingness to collaborate and foster mutually-supportive working relationships She has described how, during the early 1980s she regularly attended events organised by the Socialist Worker, went to conferences run by the Organisation for Women of Asian and African Descent (OWAAD) in Leeds and London, and that her dedication to collective Black feminist activism both led her to, and was informed by, her work at the first Asian women's refuge in Leeds. ${ }^{6}$ In 1981, with Bhajan Hunjan, she organised the exhibition Four Indian Women Artists at Indian Artists (UK) Gallery. The show, which included work by Burman, Hunjan, Vinodini Ebdon, and Naomi Iny, was not overtly political, and of the four artists' work, Burman's was unique in its direct address to socio-political issues. But the exhibition was, in its-self, intended as a feminist gesture. Significantly, Rozsika Parker and Griselda Pollock identified Four Indian Women Artists as the first exhibition of Black Women artists in their book, Framing Feminism: Art and the Women's Movement 1970-85. ${ }^{7}$ For Burman, undertaking such curatorial projects, and the processes of art making itself, was a way of trying to "understand what is going on in the world", 8 and her position as a woman of Punjabi descent, in relation to contemporary events. She was, as Solani Fernando has identified, "one of the first Black women artists in this country to produce political work", ${ }^{9}$ and Burman's prints, montages and multi-media works reflected her vocal criticisms of racial, gender, and class inequalities.

\section{Convenience, Not Love}

Convenience, Not Love was first displayed in the exhibition Along the Lines of Resistance: An Exhibition of Contemporary Feminist Art, 1988, at the Cooper Art Gallery, Barnsley. ${ }^{10}$ Curated by Sutapa Biswas, Sarah Edge and Claire Slattery the show sought to promote female artists in a collaborative curatorial setting. Burman's work was created in silk-screen and laser print, with collage, and utilises photographs from her family album, hand-drawn vignettes, newspaper imagery and popular visual culture to connect past migrations with the present lived experience of South Asian communities in Britain. The explicit use of passport covers from Britain and South Asia addresses the migration of non-white Commonwealth citizens to Britain during the post-war period, and its two parts have been understood to "represent the two 
sides of post-imperial immigration laws, with British law and its enforcement on one side and the diverse forms of Asian diasporic experience on the other". ${ }^{11}$

Since its inclusion in Along the Lines of Resistance, Convenience, Not Love has been exhibited a number of times, notably in Burman's solo show at the Horizon Gallery in 1990, and more recently in the exhibition The Place is Here, staged at Nottingham Contemporary and then Middlesbrough Institute of Modern Art (MIMA) in 2017. ${ }^{12}$ Comparing installation images of the work from 1988 and 2017, and its reproduction in her 1995 monograph, ${ }^{13}$ it is evident that Burman has reworked the diptych over the years. In its earliest exhibitionary outing the panels were hung in the opposite order, and as Deborah Cherry has recounted, they have also been displayed vertically stacked, and in darker, mahogany-coloured frames. ${ }^{14} \mathrm{~A}$ close analysis of archival images also reveals that Burman has not only changed the arrangement of some original components since its initial display but has also added material, notably the Sri Lankan passport and a reproduction of one of her own Autoportraits. ${ }^{15}$ These amendments have not dramatically changed the work, but arguably both refined and enhanced the force of Burman's commentary on the subjects that the work addresses; this paper will consider the work in its present form.

Burman's use and combination of a number of artistic techniques, and her willingness to modify Convenience, Not Love over time, is indicative of the artist's antihierarchical conception of, and approach to, art-making. Blending styles and materials, printed ephemera, photomontage, and silkscreened motifs are interrupted and intersected with hand-drawn or applied textual and decorative additions. Having worked consistently in photo-silkscreen and etching during the early 1980 s, this was one of Burman's first, and arguably, most ambitious attempts at harnessing the various techniques of assemblage. Utilising collage and montage, whereby images and visual resources have been selected, cut or manipulated, and positioned in proximity, Burman attempts to address the multiplicity of South Asian identities within a British context. In harnessing these working practices, Burman's diptych seems to corroborate Kobena Mercer's assertion that "the formal dynamics of collage ... [are] especially relevant to the hyphenated character of diaspora identities", ${ }^{16}$ wherein the possibility of combining discontinuous, playful, referential and indexical imagery is in-itself reflective of a lived diasporic experience. 
While collaged images jostle for attention, it is in the relative spatial calm of the shimmering golden ground that the isolated photo-silkscreened figure of Thatcher is able to become a point of orientation. The lone, upright figure of the Prime Minister dominates the left-hand panel, and with her arms are folded across her body, she is dressed as John Bull, standing in front of a Union Flag. ${ }^{17}$ John Bull is a fictitious character, epitomising a particular form of English nationalism and British imperialism. ${ }^{18}$ The figure first appeared in a political satire in 1712 and he was quickly adopted in the popular press as a "down-to-earth, liberty-loving, beerdrinking, and pugnacious admirer of all things English". ${ }^{19}$ By the Victorian era, the visual characteristics of John Bull, dressed in a frock- and waist-coat were widely reproduced in the work of satirical cartoonists John Leech and John Tenniel; for many at home, he stood as an English-everyman led by common sense, while abroad he was increasingly understood as "an aggressive imperialist", ${ }^{20}$ both jingoistic and protectionist. Miles Taylor has recounted that after the First World War, he was regarded as "a symbol of imperial nostalgia". ${ }^{21}$ For Burman, John Bull was then, an apposite figure when constructing a visual indictment of Thatcher and the political ideologies that she stood for. As Raphael Samuel recorded, "in the run-up to the 1983 election, Mrs Thatcher annexed 'Victorian Values' to her party's platform and turned them into a talisman for lost stabilities". ${ }^{22}$ Despite an ambivalent attitude to the historic past, Thatcher presented her ideology in terms of common-sense traditionalism, based on hard-work and thrift, which had national best-interests at its core. If Thatcher's moralizing tone and rejection of permissive modernization appealed to many, it was also satirized in visual culture, notably in Peter Kennard's photomontage of Thatcher as Queen Victoria, Maggie Regina, 1983.23 Burman's presentation of Thatcher as John Bull follows this radical, satirical visual lineage, and the Prime Minister's position in front of the British flag may be understood at a multilayered critique that encompasses not only her protectionist (exclusionary) immigration policies (discussed below), but also the jingoism that she fostered during the Falklands War, 1982, which she continued to espouse in the years following.

Thatcher's particular hostility to those who would upset her particular vision of Britishness is captured in Convenience, Not Love through the use of a vivid green 
speech bubble that expands from her mouth. The words in gothic script read: "That if there's any fear that it might be SWAMPED people are going to react and be rather HOSTILE". This text repeats the words spoken by Thatcher during a television interview in 1978, and refers to the apparent fears of ordinary -white- British people that their country might be swamped with foreigners should immigration remain at current levels; indeed Thatcher suggested that immigration from the Commonwealth and Pakistan, where Burman's ancestral family were from, was unsustainable:

\begin{abstract}
"Well now, look, let us try and start with a few figures as far as we know them, and I am the first to admit it is not easy to get clear figures from the Home Office about immigration, but there was a committee which looked at it and said that if we went on as we are then by the end of the century there would be four million people of the new Commonwealth or Pakistan here. Now, that is an awful lot and I think it means that people are really rather afraid that this country might be rather swamped by people with a different culture and, you know, the British character has done so much for democracy, for law and done so much throughout the world that if there is any fear that it might be swamped people are going to react and be rather hostile to those coming in". ${ }^{24}$
\end{abstract}

Reiterating the need to curb immigration and protect Britain, Burman has positioned Thatcher aside a tangle of barbed wire, beyond which is a British passport, flanked on its other side by a phalanx of riot police printed in blue, black and purple. ${ }^{25}$ This composition appears as though Thatcher and the wire form a double line of defense: protecting the passport from the unruly masses in the other half of the diptych; the police on stand-by should they be required.

From her sparse, but aggressively protected utopia and looking towards her left, Thatcher seems to be speaking about, and possibly giving a warning to, the people who populate Burman's right-hand panel. Here, family photographs, press images, and found and hand-drawn cartoon strip imagery, jostle and circulate around the central row of South Asian passports. From a distance the disorderly assemblage of figures appears as a manifestation of the 'swarms' of Asian people about whom Thatcher speaks, and who threaten to spill over, or jump across the divide of the diptych, into the luminous golden land that she fiercely protects. If the components of 
the left-hand panel - the passport, the flag, and the figure of Thatcher - signify Britishness, the right-hand panel may be understood to mimic perceptions of the undifferentiated South Asian 'other'. While the passports from Sri Lanka, Pakistan, India and Bangladesh are themselves exclusionary documents of statecraft, and may, in different arenas be understood as tools for the construction of national(ist) identities in the post-Independence era, they are, I suggest, used in Burman's work to subversively mimic and highlight the way in which nuances, differences and tensions between and within Asian identities are rendered indistinct from the position of Thatcher's white Britain. In this reading the populous framed within the right-hand panel are simply an unwanted, Asian-other; a threat to national sanctity.

\section{Welcome to Britain}

Homi Bhabha has suggested that the articulation of cultural difference challenges perceived national unity: "Counter narratives of the nation that continually evoke and erase its totalizing boundaries - both actual and conceptual - disturb those ideological manoeuvres through which 'imagined communities' are given essentialist identities". ${ }^{26}$ Or, in other words, the ability of non-white migrants to cross British borders, while also making claims to their own Britishness, disrupted the possibility of an "imagined community", ${ }^{27}$ in which a white populous is united by common descent and ethnicity, and shared language and cultural practices. While, in principle, any subject of the British empire had the right to reside in Britain, stand for Parliament and join the armed forces, throughout the twentieth century, successive governments sought to limit the immigration of black and Asian migrants from the Empire and then Commonwealth. The conundrum faced by UK governments was how to distinguish between British subjects without undermining the outward 'imperial rhetoric of 'equal rights for all British subjects' and civis Britannicus sum".28

Immigrants from British India prior to the First World War have been characterised as a transient group encompassing "ayahs, lascars and princes", ${ }^{29}$ who travelled according to the imperial policy of free movement. However, during the inter-war period, Indian seamen were identified as a 'problem' following violent inter-racial clashes in the shipping ports of Glasgow, South Shields, Liverpool and Cardiff in 
1919. The 1919 Aliens Act, followed by the 1920 Aliens Order, and the 1925 Special Restriction Order (Coloured Alien Seamen), each extended the 1914 Aliens Restriction Act, which had been introduced during war time and had obliged foreign nationals to register with the police, restricted where they could live, and their employment opportunities. Through these various Acts and Orders, the government developed what Ian Spencer has described as a series of regulations for "keeping out British subjects they did not want" ${ }^{30}$

The Second World War saw larger numbers of Asian - mainly male - workers and service personnel arrive in Britain. Indian seamen were now regarded as a reserve of labour, who could undertake the jobs left by British merchant seamen who had joined the war effort. However, after the war, a British policy of administrative obstruction sought to ensure that migrants did not settle in Britain. Applications by prospective migrants for British passports at local High Commissions, whether in Calcutta or Kampala, could be subjected to lengthy delays, bureaucratic systems and purposefully opaque communication of their rights as British subjects. After the 1947 partition of British India, the British government exerted pressure on the newly formed governments of India and Pakistan to establish exacting controls on emigration. The issuance of Indian and Pakistani passports was closely controlled; emigrants were required to prove that they could support themselves financially or pay a repatriation bond; in 1955, the Indian Ministry of External Affairs issued a directive "preventing the migration to Britain of Indians with low educational and financial qualifications", ${ }^{31}$ and in 1958 Pakistan required those applying to travel to Britain undertake an interview in order to demonstrate proficiency in English language, and prove that they had a job waiting for them or that they had been accepted into a recognised educational establishment. For the British, it was desirable to limit 'coloured' migration, without the use of openly discriminatory legislation, which would be damaging for fledgling post-imperial/ Commonwealth relations; it realised however, that it could retain its public 'open door' policy by passing responsibility for stemming the flow of migrants to governments of newly independent Commonwealth countries.

Such was the success of Britain's policy of obstruction, immigration from South Asia was limited during the 1950s, when compared to migration from the Caribbean, 
Ireland and Europe. However, 'coloured immigration' became a national concern when riots broke out in Nottingham and London in 1958. Although initiated by white youth, these attacks were commonly regarded "as the response of local people who felt resentful against black immigration". ${ }^{32}$ Apologists justified the violence by arguing that the inner-city areas in which black and Asian people lived had become overcrowded, and notorious for prostitution, drugs and knife-crime. ${ }^{33}$ Although steps were taken to ensure that subsequent legislation did not appear to endorse this view, the Commonwealth Immigrants Act was passed 1962. For the first time British law distinguished between "the rights of British subjects born in Britain and holding British-issued passports and British subjects who held passports issued by other Commonwealth governments". ${ }^{34}$ The Act did not specifically legislate against the immigration of non-white people, but rather introduced a system of employment vouchers which could be applied for; in practice, white immigrants from former settler colonies- Australia, Canada and New Zealand- found it easier to obtain entry into Britain. The Labour Party leader, Hugh Gatskell, described the Act as a "plain anti-Commonwealth measure in theory, and a plain anti-colour measure in practice". ${ }^{35}$

When the Labour party came to power in 1964, it introduced the 1965 Race Relations Act, which while inadequate, was a first step towards recognising the rights of black and Asian settlers in Britain. However, when, in February 1968 10,000 East African Asians entered the United Kingdom, most using British passports, following their expulsion from Kenya, the government rushed through the 1968 Second Commonwealth Immigrants Act in three days. The 1968 Act removed the right of Commonwealth members to move to Britain, despite holding Britain passports, unless they could prove an ancestral link to the country. The Act was condemned by the International Commission of Jurists, who saw it as "unprecedented discrimination by creating a category of British citizens deprived of the right to enter the territory of a country of which they are nationals". ${ }^{36}$ Enoch Powell's infamous "rivers of blood" speech of the same year, inciting racial hatred, had been the culmination of nearly a decade's worth of campaigning to keep Britain white. ${ }^{37}$ As Michael Dummett has concisely noted, 1968 marked a moment when "the British public was desperately opposed to immigration; and by 'immigration' it understood only the entry of people with black or brown skins". ${ }^{38}$ 
The 1971 Immigration Act consolidated the 1968 Act and as Spencer notes, "abolished the last vestiges of the old Empire-embracing concept of British subject or citizen". ${ }^{39}$ Henceforth, "historic categories of 'alien' and 'British subject', that used to divide the world into those from the Empire/Commonwealth who had rights and privileges in the United Kingdom and those foreigners who did not, were replaced by the essentially racially-defined categories of 'partrial' and 'non-patrial"'. ${ }^{40}$ Patrials were defined as those born or naturalised in the UK, or those who had a parent or grandparent born or naturalised in the UK. The act also put an end to the automatic entitlement of spouses and dependants to be allowed entry on the basis of their partner or family member having British citizenship. As a consequence, the "rights of nonwhite commonwealth citizens to settle in Britain ended with this act". ${ }^{41}$

However, despite legislation, 'coloured' immigration remained at the forefront of political debate as racial tensions mounted; in 1970s Britain, it seemed that 'pakibashing' became a national sport. ${ }^{42}$ In 1978, Margaret Thatcher's comments about Britain being swamped with immigrants from the Commonwealth "were widely condemned as pandering to popular prejudices and even as 'giving aid and comfort to the National Front"". ${ }^{43}$ Nonetheless, eight proposals to further increase immigration controls were included in the Conservative Party's election manifesto in April 1979. When Thatcher's newly formed government introduced the 1981 Nationality Bill, which was "virtually explicit in its design to ensure second-class citizenship for nonwhite people", Kum Kum Bhavnani, observed that "we can see how little difference there is between the racism of the National Front and the Conservative Party". ${ }^{4}$

Although Britain remains largely estranged from the intricacies of its colonial past, and the realities of its exclusionary immigration practices, the creation of South Asian diasporas in Britain is undeniably a colonial legacy; as the Sri Lankan scholar Ambalavaner Sivanandan reminds us,

we came to Britain (and not to Germany for instance) because we were occupied by Britain. Colonialism and immigration are part of the same continuum - we are here because you were there. ${ }^{45}$ 
However, hostility towards the Asian diaspora is presented in Convenience, Not Love as a symptom of a double standard in which it was, as the title suggests, convenient for Britain to accept migrant labour in the post-war period but only on its own terms. Although a large proportion of South Asian migrants came to Britain by their own initiative, Britain continued to exploit its former colonies in the era of Independence. Many new arrivals, especially those from East Africa, found they could only secure employment in low skilled manual jobs, for which they were over qualified. In the left-hand panel, a graphic presentation of a caricatured male figure, wearing a rounded (bowler?) hat mingles haphazardly with policemen pictured in full riot-gear. Printed in multiple, the red figures wear sandwich boards bearing the slogan, "Come to Britain for Jobs". The man, with his peculiarly shaped moustache, bears a resemblance to Enoch Powell, who as Minister for Health in the Conservative government, actively recruited nurses from the Caribbean to work in the National Health Service between 1960 and 1963. While South Asian workers were not recruited in such direct ways, ${ }^{46}$ the cartoon figure nonetheless encapsulates the way migrants were necessary to the British economy, while the use of gold in the left hand panel evokes the promise that Britain was a land of opportunity. However, Thatcher's stance, together with the barbed wire and riot police, presents an hostile and exclusionary reality.

Telescoping time across the two panels, it appears as though Thatcher, from the 1980s, is not only speaking to, but looking at South Asian migrants who arrived in Britain during the 1950s and 60s. The new arrivals included people from a range of social, religious, and educational backgrounds, from the sub-continent and East Africa, but in her selection of certain figurative images, Burman both demonstrates and undermines stereotypical visual tropes of the homogenous Asian other that circulated in the British popular press. A number of male figures arrive in Britain with their luggage. In the lower right corner is a man carrying a suitcase in each hand. Holding his Indian passport, he steps forward into a capitalised handwritten text: "WELCOME TO HEATHROW", which is interwoven with sterling currency symbols (£) rendered in gold; the welcome mat is seemingly laid out to meet him. He is smiling, and Burman's use of gold echoes the golden ground of the left-hand panel. The man has come to make his fortune and capitalised text announces his intentions: "HERE TO STAY!!". This expectant and eager figure is contrasted somewhat by 
another man, sitting on a bag, patiently alone, and encircled by suitcases and a rolled mattress. Utilising a photograph by (John) Topham of a Sikh traveller at Victoria Station, London, in 1959, ${ }^{47}$ here, Burman's visual meditation on economic migration bears similarity with a passage in M.G.Vaaanji's 1989 novel The Gunny Sack, in which the main character, on arriving at Heathrow asks:

And how does Britannia treat her offspring who come from all over the world to pay their respects? At the Airports, lines, long lines: coloured, white, coloured, white... A coincidence? Hardly. First and second class British subjects. You look at the others in your line, and you wonder, am I one of these ${ }^{48}$

\section{Passport Control}

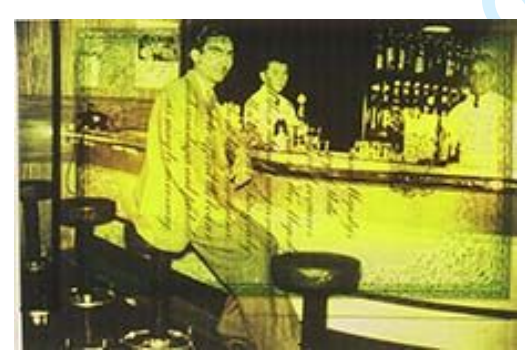

Fig.2, Chila Kumari Burman, Dad on ship- arriving in Britain 1950s, Cibachrome print, 1995

The figure of the lone male migrant had particular personal relevance for Burman, and in the cibachrome print of 1995, Dad on ship-arriving in Britain she addressed the specificities of her familial biography (fig.2). In this work, a photograph of the artist's father in the act of migration is overlain with the text and decorative borders found on the inside cover of a British passport. Mr. Burman travelled to Britain on the MS Batory, which docked at Southampton on 4 March $1954 .{ }^{49}$ In the photograph Mr. Burman sits on a stool at a bar; behind the counter stand two bartenders, dressed in white jackets and black ties. His posed is relaxed; one elbow rests on the counter-top, his other arm is placed on his thigh; he looks directly at the camera with a faint smile on his face. He is perhaps mid-journey, aboard the ship transporting him from India to Britain, anticipating his safe arrival; that he should be so assured is underscored by the passport text which reads: 


\begin{abstract}
“Her Britannic Majesty's Secretary of State Requests and requires in the name of her majesty all those when it may concern to allow the bearer to pass freely without let or hindrance and to afford the bearer such assistance and protection as may be necessary."
\end{abstract}

\begin{abstract}
Mr. Burman is presented as one of those British subjects who came to the mothercountry in the 1950s before revised British immigration law made such movement difficult. Due to his possession of a British passport, Mr Burman is not only assured safe passage, but also assistance should he so require it. It is this sense of security that perhaps facilitates his easy demeanor.
\end{abstract}

As Darren J O'Byrne has outlined, the passport has a number of functions, including, but not limited to: "proof of citizenship; proof of identity in general; currency empowering one to cross borders; request by the sovereign to the foreign authority to allow safe passage; some assurance of protection for the bearer by the sovereign while in a foreign country". ${ }^{50}$ Introduced as a security measure prior to the First World War, the passport became a method of surveillance and tool for national security; following the 1915 Defence of the Realm Act, all British citizens were required to hold a passport when leaving or entering the country, and the same year, the colonial government of British India introduced the Defence of India (Criminal Law Amendment) Act 1915, which included the Defence of India (Passport) Rules, which "made embarking on a journey from any port in British India without a passport a criminal offense". ${ }^{51}$ From 1916 photographs as a visual form of identification were required in British passports; these portraits were, and remain, banal images, created according to strict and standardising criteria. However, the "putative transparency" 52 of the passport as a representational sign of belonging to a nation-state belies its power as a tool for discrimination. Lily Cho has argued that, "While the passport may seem relatively benign ... the consolidation of its usage attests to a long history of state suspicion leveled with particular acuity upon anyone who does not want to stay put". ${ }^{53}$ As Mr Burman and many others in his situation discovered, possession of a British passport did not guarantee a hospitable welcome.

John Torpey has argued that the development of the passport in the modern era also illustrates the "institutionalization of the idea of the 'nation state' as a prospectively 
homogenous ethnocultural unit". ${ }^{54}$ For Torpy, the state monopoly on individual freedom of movement and the right to settlement - as facilitated or denied by the passport - also allowed the state to cultivate and maintain a particular ethnocultural population. Since passports were issued at the discretion of the state, and from at least 1968 according to legally defined conceptions of nationality based on familial lineage, or naturalization, it was very difficult for non-white British subjects to successfully obtain a British passport. Indeed, although the 1971 Immigration Act actually increased the number of people entitled to a British passport, because these comprised people of European extraction with historic familial origins in Britain - i.e. white - , this increase was not of popular or political concern. For Radhika Viyas Mongia, the passport thus emerges as a state document that successfully "conceal[s] race and racist motivations for controlling mobility". ${ }^{55}$ She concludes her compelling analysis of migration within the British Empire in the early twentieth century by arguing that while we may think of the passport as a document that facilitates movement, "its history reveals that it is born out of an attempt to restrict movement along national lines that are explicitly raced". ${ }^{56}$

In her use of national passports in Convenience, Not Love Burman places the signifier of Britishness at a distance and separate from the four South Asian signified national identities; in this act of differentiation Burman physically positions white and Black ethnicities in opposition, while simultaneously challenging the normative conceptions of Britishness based in whiteness, and the imagined exclusivity of British and Asian identities. It is the ideologically essentialized British identity that Thatcher protects, but as Bhabha asserted, the presence of the other undermines that imagined community. Burman's incursions onto the British passport offers a counter narrative, leading to questions over who, or what, Thatcher is protecting. In the windows of the passport cover, which would usually contain the holder's name and passport number is instead, Urdu script. Written by the artist's father, the text is unambiguously and provocatively 'foreign', and reads:

"You allow us to come here on false promises. We come here full of hope and destiny. You have no mercy. We will struggle and survive. Long live. Long live. Long live". 57 
From the scene of anticipation aboard the ship, or the excitement of arrival at Heathrow, the male migrant making his way in the world is, according to the Urdu text, maltreated but not dispirited. Anticipating a hospitable welcome and arriving in Britain with aspirations of economic prosperity, here the message seems unequivocal: that migrants were permitted in Britain on expedient terms. The symbols of protection, barbed wire and riot police suddenly become those of threat. Held within the passport windows, the Urdu text is contained, and as such the two signifieds Britishness and Asianness - remain in antagonistic relation. Positioned as it is in the left hand panel, it is unclear whether the Urdu-British passport is being protected or attacked, epitomising the ambivalences within British society. ${ }^{58}$

But, if the Urdu script is understood as an accusation and statement of defiance, then Convenience, Not Love in its totality may be understood as a scathing critique of British immigration policy, a commentary on the institutionalized racism that impacted on the everyday lives of ordinary working class people, and the hypocrisy of successive British governments over who has the right to settle in Britain. Significantly, Burman's construction of this work as a diptych asserts the divisions and exclusions faced by migrants to Britain; the format of the work being indicative of the lived situation of many of Britain's diasporic communities, living alongside, but never fully within the purview of Britishness. What is at stake in this work then, is the issue of whether Britain's subjects from the former Empire are truly British. As Rina Arya has suggested, "The passport may be a visible reminder of her legal status, but it does not guarantee the sense of feeling at home". 59

\section{Meek and Passive Victims?}

Convenience, Not Love presents a non-linear, entangled meditation on South Asian migration, and although experiences of male migrants are fundamental to the work, it is the status of women that drives Burman's anti-essentialist work. If the singular and isolated image of Thatcher recalls her political prioritization of the individual at the expense of the community at large, she is contrasted with multiple images of women in a range of quotidian, sociable and socially engaged activities in the right hand panel. To understand the radical nature of Burman's presentation of South Asian femininity, it is necessary to appreciate just how derogatory public, institutional, and 
counterintuitively (white) feminist perceptions of Asian women were, in Britain during the late 1970s and early 1980s. Although the British South Asian diaspora includes people from different social classes, religions, and castes, and as such, women with different socio-economic and political agency, in 1984, Parita Trivedi asserted that Asian women in Britain were regarded as servile, "beaten-down", shackled, after generations of colonial misadventures and familial oppressions. ${ }^{60}$ Within this context, Burman's presentation of women in Convenience, Not Love should be regarded as an attempt to counter hegemonic political and visual discourses in Britain, which, as film-maker Pratibha Parmar observed, stereotyped Asian women as "meek and passive victims". ${ }^{61}$ This stereotype of Asian women was exacerbated by British immigration policy; most women migrating to Britain from the Indian subcontinent came to join husbands and fathers who had already undertaken the journey. ${ }^{62}$ These female migrants were regarded as dependents, and were not conferred citizenship in their own right, but rather, were allowed to remain in Britain on the basis of their marriage; should marriages end in divorce or widowhood, women were liable for deportation. As such, South Asian women were not regarded as active agents in their own lives. At one level of interpretation, the image in the top left of the right-hand panel is indicative of the presentation of Asian woman as submissive that received widespread circulation in Britain as large numbers of Asian refugees arrived from Kenyan and Uganda in the 1970s. A group of women are shown crouched and huddled together; some wear scarves covering their heads, nearly all look directly out at the viewer, somewhat expectantly. However, in quoting this photograph Burman challenges its veracity; her modifications of it indicate a self-conscious subject position that was at odds with the stereotype to which she herself was expected to confirm. The photograph is hand tinted, adding vibrant colour to each figure, while one woman has also been adorned with a glistening jewelled bindi. The effect of these interactions with the image is to give each woman her own subjectivity; and in putting this image alongside those with more assertive depictions of South Asian femininity, Burman creates a dialogic space in the right-hand panel in which to rethink South Asian womanhood.

Below the row of South Asian passports is a hand-drawn cartoon strip that narrates the common experience of female migrants. A young girl with thick black braids tells a familiar story of migration to a blond-haired youth: Her uncle came to Britain to 
work in the 1950s, and having saved enough money, later sent for his wife and son the join him. They waited nineteen months for an interview with immigration officials, who, with the aid of a translator who spoke a different dialect, queried whether or not they were related. Interviews, we are told, were not recorded, and as paperwork mounted, errors were not corrected. For those who made it to the UK, the young narrator sardonically asks, "did you know that immigration officers expect to receive answers to questions they haven't asked? ... and until 1979 women were forced to have internal examinations to verify virginity". In the penultimate frame the blond character suggests that, "for the people who are here, all's well that ends well, eh!". Not so, says the girl, "the threat to their security continues here from the police". The narrative concludes ominously, "their troubles were just beginning..."

Reference in this graphic narrative to internal medical examinations endured by female migrants accounts for the prevalent critical interpretations of Convenience, Not Love. When it was included in Burman's solo show at The Horizon Gallery in 1990, Nina Perez noted in her review that the diptych "deals with brutal immigration laws, virginity tests and asserts the fact that despite all this Asian people are here to stay". ${ }^{63}$ Lynda Nead similarly concluded in 1995 that "the work deals with immigration laws and the virginity tests which determined the entry of Asian women into Britain". ${ }^{64}$ Virginity testing was controversially exposed by the Guardian newspaper in February 1979. It reported how, on 24 January, a 35 year old Indian woman arriving at Heathrow had been subjected to an internal examination in order to determine whether or not she had previously had children. On the basis of this information, it was believed possible to determine whether or not she was still a virgin. And on the basis of this so-called virginity-test, her application to enter the UK to marry her fiancé would be decided. ${ }^{65}$ Such was the paranoia surrounding non-white migration to Britain, South Asian women were regarded with particular suspicion by British immigration officers who believed that many were fraudulently participating in arranged marriages in order to obtain a British passport; as the title of Burman's work suggests, they were considered brides of convenience, not romantic love. Despite government assertions that the case exposed by the Guardian was unique, virginitytesting regularly took place, whether in the UK, or with the cooperation of local officials prior to the women's departure from the subcontinent. ${ }^{66}$ And as Parmar has noted, these gynaecological examinations were carried out on the assumption that 
Asian women were always virgins prior to marriage, itself an "absurd generalization ... based on the same stereotype of the submissive, meek and tradition-bound Asian woman" ${ }^{67}$ Regarded in this context, the equivocal nature of Burman's title becomes striking; In a recent conversation, the artist has explained that although the phrase 'convenience, not love', may refer to economic migration (as described above), when she made the work, the issue of virginity-testing and arranged marriages was at the forefront of her mind. ${ }^{68}$

The treatment received by Asian women seeking to enter the UK is starkly contrasted in Convenience, Not Love by the inclusion of a single black and white newspaper photograph of the controversial South African athlete Zola Budd in the left-hand panel. If female South Asian migrants were treated with particular suspicion, Burman's use of Budd's image serves to further highlight the flagrant inequalities faced by women of colour at the border, starkly demonstrating how British immigration policy established first and second class British citizens. Positioned amidst the policemen and the Powell-like figure inviting migration, the newspaper image shows Budd in the act of crossing the finishing-line in first place: she is presented as a success and therefore welcome in Britain. Although born in South Africa, in 1984 the Daily Mail newspaper initiated a campaign to grant Budd British citizenship. The then 17-year old runner was a prodigious talent, who was unable to compete on the international stage because of the ban on South African athletes at international sporting events- part of a strategy of sanctions in response to the continuance of South Africa's apartheid system. Having established that Budd's father was British, the newspaper published campaigning articles on its front pages, and lobbied the government to grant the athlete British citizenship. In just 10 days, Budd's application for citizenship was submitted and approved by the Conservative government. ${ }^{69}$ It is worth noting that at a time when Burman and others were expressing solidarity with black resistance in South Africa, in 1984, the year Budd was granted British citizenship, "Thatcher became the first British prime minister in 23 years to host an apartheid head of state". ${ }^{70}$ It is perhaps little wonder then, that in Burman's artwork, Budd is protected by a coterie of riot police.

However, Burman's artwork also demonstrates that many South Asian women did not simply accept their assigned status as second-class citizens, but rather drew on a 
matrilineal history of anti-colonial struggle to challenge British hierarchies of power. Alongside the more prosaic images of women washing clothes, cooking and laughing together, Burman also positioned images of historical and contemporaneous female defiance (see fig.6). Images of radical women from the Indian subcontinent include a popular comic-book rendition of Lakshmibai, the Rani of Jhansi, pictured on horseback dressed in elaborate body amour and brandishing a sword; in 1857 she had led the Indian rebellion against the British in imperial India. She is accompanied by popular images of other "valiant Queens" sourced from children's graphic novels: Rani Durganati, who ruled the region of Gondwana between 1550 and 1564, and Raziya Begum, known as Razia Sultan, who was the Sultan of Delhi between 1236 and 1240. Other images depict women on protest marches - both in the UK and in India - holding placards, carrying sticks, and chanting into loud speakers. One watercolour vignette presents a woman shouting into a loud hailer, demanding a public enquiry, while a hand-tinted press photograph records the 1976-78 picket line of striking female workers at the Grunwick Film Processing Laboratory, north London. In their unambiguous affirmation of female agency, Burman's aggregated community of women challenge value-laden assumptions of South Asian womanhood in Britain and demonstrates an awareness of the need for images that counter prevailing discourses of race and gender. Here the multiplicity of drawn, collaged and printed images is disruptive and dynamic; pictorial coherence or compositional stability is denied: harnessing the material and formal qualities of her assemblage technique, Burman demonstrates the pluralities of South Asian female experience: refugee, economic migrant, homemaker, Queen, revolutionary.

\section{Working Women}

Although Burman has stated that it was her father who wrote the Urdu text in the British passport windows, giving the phrases a male voice, the words may equally be spoken by her female protagonists. As Amrit Wilson recounted in her landmark 1978 feminist text, Finding a Voice: Asian Women in Britain, having endured degradation and humiliation in order to arrive in Britain, South Asian women were then faced with a myriad of other hurdles and challenges in the workplace, where ethnic stereotypes were used to justify inequalities. ${ }^{71}$ Since wives and daughters were usually classified as dependents, British officials had not anticipated that they would enter the 
workplace. In fact, large numbers of South Asian women did work, but, as Amina Mama recorded, with other Black women they "are to be found in the lower echelons of all the institutions where we are employed ... where the work is often physically heavy ... the pay is lowest, and the hours are longest and most anti-social" ${ }^{72}$

Working class South Asian women often found themselves "invisible", ${ }^{73}$ but as Burman makes clear in the right-hand panel of Convenience, Not Love they were not only active in the workplace, but vocal in the face of discrimination. In 1974, an industrial dispute led by Asian women at the Imperial Typewriters factory in Leicester resulted in workers walking out on the discovery that white women undertaking the same jobs were earning more money. ${ }^{74}$ Although, as Wilson recounts, "strikers returned to work having won few concessions", 75 it was nonetheless a galvanising experience for them. Burman's inclusion of images on the Grunwick picket-line bears testament to the force of Asian women and their demand for equitable treatment. In 1976-7 the Grunwick strike was led by Jayaben Desai and the picket line constituted the mainly female Asian workforce unwilling to accept poor pay, sexual provocation and degrading treatment by the white managers and owners. ${ }^{76}$ The Factory management sought to use their preconceived understanding of Asian patriarchy as a mode of control, arguing that those on the picket line brought shame on their families. However, reflecting on the strike and its legacy, Wilson observed:

"No one, least of all Asian women workers themselves, would claim that they are highly militant or strong. What they have been in the past, in the face of their grim working lives, is resilient. They have refused to despair, accepting quiet stoically that they have been given. Now this stoicism is changing. Partly it is changing because women are getting more familiar with the industrial scene and partly because of the tremendous impact and influence of the strike at Grunwick Photoprocessing [sic]. That strike has proved for always that Asian women workers can be strong, resourceful and courageous, that they can stand up, face the world and demand their rights". ${ }^{77}$ 


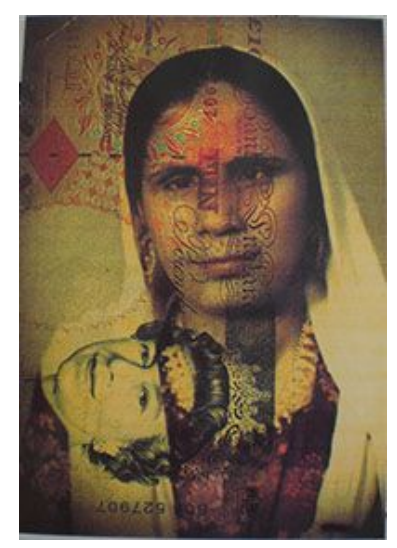

Fig.3, Chila Kumari Burman, Portrait of Are Mum, Sweet Flower, 1994.

Wanting to take control of representations of her own working-class culture, in the early 1990s Burman produced a series of prints in which she combined archival family photographs with British currency. In Portrait of Are Mum, Sweet Flower, 1994, a colour photograph of the artist's mother is overlain with the design of a ten pound note (fig.3). Mrs. Burman is dressed conservatively, with a shawl covering her head, and she looks demurely to lower left. The ten pound note is positioned vertically, so that the portrait of Queen Elizabeth II is positioned at a 45 degree angle and she seems to float just below Mrs. Burman's chin. The decorative script and graphic embellishments of the money appear inscribed tattoo-like on Mrs. Burman's face. Discussing this work Orlando suggests that the combination of the British monarch with "the face of a South Asian woman, creates an immediate reference to the history of imperialism", ${ }^{78}$ while Meena Alexander asks, perceptively, "What does it mean to write over a mother's face, layering over a mother with the imprimature of a colonial state?". ${ }^{79}$ For Alexander the work is infused with a "subtle tension" in the interplay of two contradictory depictions of motherhood. ${ }^{80}$

If the British Monarch - national mother - is here rendered as symbolic of colonial exploitation for financial gain, the chosen image of Mrs Burman conforms to maternal stereotypes conveying a soft, nurturing sensibility. However, as with many of Burman's chosen and manipulated images, Portrait of Are Mum, Sweet Flower may be read in divergent or dualistic ways. Rather than presenting an Asian woman held beneath imperial systems, it is also possible to regard the two components, the woman and the money, in converse relation. If Portrait of Are Mum, Sweet Flower is understood to show currency stamped or overlain with the photographic image, it is 
possible to regard themes of commercial entrepreneurship and class aspirations, while also presenting a positive narrative of economic migration within the purview of Britishness. If the image of Mrs. Burman is prioritized, she is seen to take control of the money, rather than be controlled by it. In 1983 Burman proclaimed that "me mum is a really amazing, strong woman", 81 and more recently has noted that her presentation in this portrait is something of a red-herring: Mrs. Burman rarely wore saris or traditional Indian dress at home, and the artist recounts that she was rarely 'demure'. In addition to her role as a homemaker, Mrs. Burman also managed and prepared the stock for her husband's ice-cream van - Burman recalls making toffee apples in the family kitchen ${ }^{82}$ - and oversaw the cashflow of the business, counting and banking the profits at the end of each day: "Me Mum, she kept the whole thing together". ${ }^{83}$ Burman's choice of an image of her mother that apparently conformed to the passive stereotype of South Asian feminitity is then subverted by the presence of money which becomes symbolic of her financial acumen and aspiration. As such, rather than an image of a meek, sweet Mum, Mrs. Burman provides an immediate example of active womanhood. Indeed, by using family photography in Portrait of Are Mum, Sweet Flower, and Convenience, Not Love, Burman normalizes the depiction of South Asian women in a range of different activities, and highlights how women undertake numerous roles and responsibility within the family. Burman is herself present in Convenience, Not Love, pictured with her mother, alongside aunts and cousins, and as such the use of family photographs conveys a complex picture of the prosaic lived reality of South Asian women. It is my contention here that Burman's point is underscored by her mode of working, where "the politics of montage concerns the way in which we negotiate heterogeneity and multiplicity". ${ }^{84}$

\section{Burman's Radical Narcissism}

This playful and discursive approach to female portraiture was further developed in Burman's printwork during the early 1990s. In a body of work collectively titled, Autoportraits, Burman seemingly moved away from making overt political statements or reference to contemporaneous events, and instead developed an uncompromising form of self-portraiture. Significantly however, her use of her own body was in contradistinction to the dictums of the white feminist movement, that advocated a "turn away from the corporeal" and was "vehement about the absolute need to remove 
the female body from representation". ${ }^{85}$ As Amelia Jones has recorded, for many white feminist artists and critics, the presentation of the female body automatically participated in, and was subject to, phallocentric objectification; In 1982 Mary Kelly asserted that, "Most women artists who have presented themselves in some way, visibly, in the work, have been unable to find the kind of distancing devices which would cut across the predominant representations of women as object" ${ }^{86}$

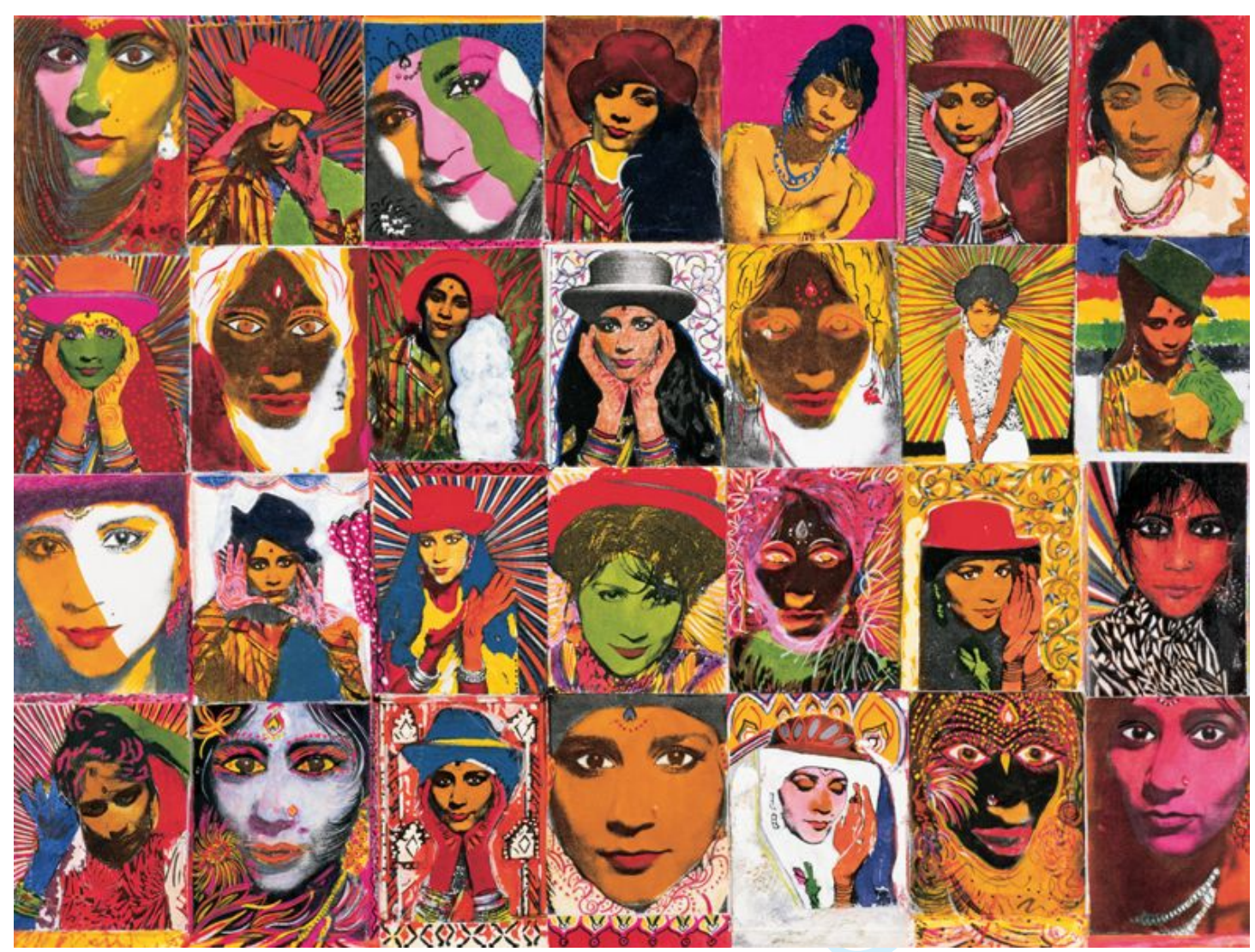

Fig.4. Chila Kumari Burman, 28 Positions in 34 Years, 1992, Laserprint and painting, 47x62 in, Birmingham City Museum and Art Gallery

However, for Black and Asian artists in Britain, where historic and contemporary representations of the female-self were limited to colonial stereotypes, the position asserted by Kelly and others was inadequate. ${ }^{87}$ In using her own self-image in works such as 28 Positions in 34 Years, 1992 (fig.4), Burman (to follow Jones), articulates a radical narcissism, whereby she "flamboyantly objectifies the female body but also simultaneously performs her body/self as subject". ${ }^{88}$ Her Autoportraits explore the intersection of her objectification as female, and exotic other, while the multiplicity of 
her self-image within a single work hinders reductive interpretations that would delimit her identity to a set of stereotypes.

In 28 Positions in 35 Years Burman offers 28 self-portraits presented in a grid of four rows of seven rectangular images. Ten of the images are tightly cropped so that the face fills the rectangular frame; others present the artists from a mid-distance, showing her head and torso; these images are notable for the way in which Burman poses with her hands, which variously cup her face, or are presented to the audience. Burman has repeated the use of several photographs, so that she is seen in the same pose a number of times; in one instance, a close-up of her face has been used in both front and reverse. Significantly, her mode of dress combines western and Asian garments; in multiple images Burman wears a tailored jacket and pork-pie hat, while also adorned with jewelled bidi, glass bangles and henna tattoos.

Rejecting the negative connotations usually associated with the word, Jones asserts that narcissism can be a radical strategy for female artists, and particularly women of colour. This is because as an exploration of the self, the narcissistic artwork, "inexorably leads to an exploration of and implication in the other". ${ }^{89}$ If the body performs (or is performed) according to its own socio-political context, this necessarily means that experiences of racial stereotyping and discrimination are already embedded within the body. Wherein "self-involvement was seen as the surest way to repudiate the objectification of women and to politicise personal experience". ${ }^{90}$ Burman's multiplied self image both enacts and exacerbates the fragmentation of the strictures placed on South Asian womanhood, asserting its heterogeneity and intersubjectivity. Her performed narcissism disrupts what Mercer has called the normative "'truth value' produced by dominant codes of visual representation". 91

That Burman regularly utilised a particular rectangular frame and facial pose that looks out at the audience in her Autoportraits, on the one-hand recalls Warhol's multiples, but might also refer to the uniform repetitions of the passport photograph. But where the passport photograph requires the sitter to present their face devoid of emotion, adhering to a standardized pose set against a neutral background, each of Burman's individual portraits in 28 Positions in 35 Years is unique in the way that she 
has interacted with, and modified, the original image. Blocked stripes, swirling spirals, dots, dashes, and linear rays rendered in an array of yellow, red, green, pink and blue variously overlay the photographic image and collectively create a frenetic composition which demands the viewer's attention, but which resist a settled viewing experience. Understood as a development of Burman's engagement with modes of identity formation, the repeated self-portraits thus question the veracity of the photographic image. She has stated, "My manipulation of the photographic image questions the idea of the photograph as a document of the empirical reality to reveal an 'image of myself'". ${ }^{2}$ For despite its memetic capture, Burman's graphic and painterly interventions on the photographic image suggest that it is always lacking. Historically, the photographic portrait has been regarded as depicting its subject and conveying their actual appearance. Thus the photograph was able to function as a system of disciplinary control and was adopted as an empirical document within the law and its enforcement agencies. With regard to the passport photograph, Cho has suggested that, "The injunction against emotion ... projects a fantasy of a passive, transparent, and readable national subject." 93 In this fantasy, the subject is conforming and easily schematized; they are neither passionate nor dissenting. However, for Cho, the hybrid qualities of diasporic personhood challenge the possibility of a neutral or conforming subject, wherein subjectivities cannot be contained within the disciplining frame of the passport photograph. ${ }^{94}$ The visual excess of Burman's Autoportraits may thus be understood as expressing a profusion of personality, which is multiple, hybrid, and dynamic. In her rich and decadently patterned Autoportraits Burman refutes the possibility that the photographic image, as purported by the passport photograph, can capture the totality of a personal - or national - identity.

\section{Picturing Resistance and Resilience}

"My work is about reclaiming the image of Asian women, moving away from the object of the defining gaze, towards a position where I / Asian woman become the subject of display. My self-portraits construct a femininity that resists the racist stereotype of the passive, exotic Asian woman, imprisoned by male patriarchal culture. Rather I become the maker and definer of my own image. Femininity is a fun, liberating force, rather than an oppressive force, allowing me to challenge the viewers' preconceptions of Asian femininity". ${ }^{95}$ 
Throughout her career Burman has garnered widespread admiration for her "unswerving commitment to a range of social and political narratives", 96 which in turn have underpinned her challenge to the oppressive parameters placed on South Asian women, both in the home, and in wider British society. In the diptych Convenience, Not Love Burman's engagement with collected press imagery, drawn vignettes, the family photographic archive, and her own self portrait, conveys a sonorous commentary of hopeful departure, optimistic transit, hostile encounter and settlement, culminating in resilient resistance. Intermingling the experiences of first generation South Asian migrants with those of the born-in-Britain diaspora, in proximity to historic and contemporaneous figures of resistance, Burman defies those limitations placed on Asian womanhood by racist stereotypes and British postcolonial anxieties. Simultaneously, Convenience, Not Love presents the British passport, pejorative visual stereotypes and discriminatory immigration procedures as tools for legitimising the exclusion of the South Asian diaspora from a national imaginary. Replicating an attempt to keep at bay the Asian populous, the two halves of Convenience, Not Love re-enact the discrimination experienced by Britain's subjects from overseas, while asserting that contemporary British identity is nonetheless formed and informed by diasporic immigration. South Asian diasporas, and specifically South Asian women, in Britain are promoted as not only radically dissenting, but entrepreneurial and resilient in the face of systematic state discrimination and work-place inequality. In response to Thatcher's warning of being "swamped", Burman harnessed the various techniques of printmaking, collage and montage in order to create a work of visual excess that unsettles both, national parameters and pictorial convention. Through the mixing and manipulation of found, made, and collated visual resources she unapologetically ruptures attempts at ethnonational exclusions and European aesthetic niceties. These visual strategies evolved into her narcissistic Autoportraits, which further refute the possibility of isolating or containing South Asian identities. Cumulatively, Burman has arguably taken Pop's twin poles of the simulacral and the referential ${ }^{97}$ and colonized them with a black feminist discourse: conjoining the spectacular of Pop, with a diasporic hybridity, in the works discussed, she maintained multiple, sometimes conflicting positions, the implications of which are subject to change according to the socio-political climate in which they are viewed. It is the contention here that these works should properly be 
regarded as a Black feminist retort, which draw attention to the complexity and multifaceted nature of British Asian identities. Chila Burman's works affectively assert South Asian identities as heterogeneous, messy, and flamboyant; British and here to stay.

${ }^{1}$ See Orlando, British Black Art, 96.

${ }^{2}$ Poovaya Smith, The Circular Dance, 11.

${ }^{3}$ Jones, Body Art, 24.

${ }^{4}$ Karimjee and Patel, 'Aurat Shakti', 42.

${ }^{5}$ Carby, 'White Women Listen!', 216.

${ }^{6}$ Conversation with the artist, 5 August 2017.

${ }^{7}$ Parker and Pollock, Framing Feminism, 64.

${ }^{8}$ Burman, 'Hiya Sisters', 53

${ }^{9}$ Fernando, 'Chila Kumari Burman', 57.

${ }^{10}$ Biswas, et al. Along the Lines of Resistance. The exhibition ran from 7 December 1988 - 22 January 1989.

${ }^{11}$ Nead, Chila Kumari Burman, 28.

12 See Sharma, 'Said Adrus's Zeitgeist'.

${ }^{13}$ Nead, Chila Kumari Burman, 30-31.

${ }^{14}$ Cherry, 'Suitcase Aesthetics', 803.

15 The Sri Lankan passport was added to the work at a later date, and was not present when the diptych was exhibited in Along the Lines of Resistance. See reproduction illustration of Convenience, Not Love in Beckett, 'Resistance, Continuity, Struggle', 5 .

${ }^{16}$ Mercer, 'Romare Bearden', 126.

${ }^{17}$ Eddie Chambers has identified this left-hand panel as an artwork in its own right, titled, You allow us to come here on false promises; however, the artist has asserted that this is incorrect, insisting that the work only exists as a diptych. See Chambers, Black Artists in Britain,88. Conversation with the artist, 5 August 2017. Nonetheless, Burman did reuse the compositional elements of the British passport, Margaret Thatcher and Union flag, in opposition to the passports of India, Pakistan and Bangladesh in her artist's page for the exhibition catalogue, The Medium and the Message.

${ }^{18}$ Taylor, 'Bull, John'.

${ }^{19}$ Taylor, ibid.

20 Taylor, ibid..

21 Taylor, ibid..

${ }^{22}$ Samuel, Island Stories, 330.

${ }^{23}$ Kennard, Maggie Regina, 1983.

24 Thatcher, World In Action. Pakistan left the Commonwealth in 1973 due to Britain's recognition of Bangladesh, and so is mentioned by Thatcher separately. Rasheed Araeen also used Thatcher's words in his mixed media artwork, Look Mamma... Macho!, 1983-1986; Space does not permit a longer discussion, but for reproduction see Aikens, Rasheed Araeen, 256-7. 
25 The navy blue British passport was replaced by the standardized EU burgundy design in 1988. However, there have been discussions about whether this 'British' design is set to be reinstated post-Brexit. See Wheeler and Tominey, 'Britain's Blue Passport RETURNS'.

${ }^{26}$ Bhabha, The Location of Culture, 149.

${ }^{27}$ Anderson, Imagined Communities, 1991.

${ }^{28}$ Spencer, British Immigration Policy, 8.

${ }^{29}$ See Visram, Ayahs, Lascars and Princes.

${ }^{30}$ Spencer, British Immigration Policy, 12.

${ }^{31}$ Spencer, ibid., 96.

${ }^{32}$ Layton Henry, The Politics of Race, 39.

${ }^{33}$ Layton Henry, ibid. 39.

${ }^{34}$ Spencer, British Immigration Policy, 134.

${ }^{35}$ As cited in Webster, 'The Empire Comes Home', 133.

${ }^{36}$ As cited by Torpey, The Invention of the Passport, 151.

${ }^{37}$ Powell's 'Rivers of Blood' speech was delivered at a Conservative Association meeting, in Birmingham on 20 April 1968. See Powell.

${ }^{38}$ Dummett, On Immigration and Refugees, 104.

${ }^{39}$ Spencer, British Immigration Policy, 144.

${ }^{40}$ Spencer, ibid., 143.

${ }^{41}$ Alibhai-Brown, Who Do We Think We Are, 72-73.

42 See Solomos.

${ }^{43}$ Layton Henry, The Politics of Race, 94. Citation from Sunday Times, 26 February, 1978, no page reference given.

${ }^{44}$ Bhavnani, 'Racist Acts', 51.

${ }^{45}$ Sivanandan, 'Catching History on the Wing'.

${ }^{46}$ See Dhondy, 'Asian Communities'.

47 The original photograph is reproduced in Dhondy, 'Legacy of the Raj', 51.

48 as cited in Marangoly George, The Politics of Home, 192.

${ }^{49}$ See $A$ Passage to Britain.

${ }^{50}$ O’Byrne 'On Passports', 403.

${ }^{51}$ Viyas Mongia, 'Race, Nationality, Mobility', 210.

52 Owens, 'Representation', 98.

${ }^{53}$ Cho, 'Citizenship', 279.

${ }^{54}$ Torpey, The Invention of the Passport, 1.

55 Viyas Mongia, 'Race, Nationality, Mobility', 210.

56 Viyas Mongia, ibid., 211.

${ }^{57}$ as translated in Nead, Chila Kumari Burman, 28-29.

${ }^{58}$ See Piper, 'Body \& Text', a visual essay in which Piper presents the British passport as an ambivalent tool of colonial domination and oppression.

${ }^{59}$ Arya, Chila Kumari Burman, unpaginated.

60 Trivedi, ibid, 38.

${ }^{61}$ Parmar, 'Black Feminism', 116.

${ }^{62}$ Parmar, 'Gender, Race and Class', 241.

${ }^{63}$ Perez, 'Chila Kumari Burman', 31.

${ }^{64}$ Nead, Chila Kumari Burman, 28.

${ }^{65}$ See Smith and Marmo, 'Uncovering the "virginity testing" controversy', 161.

66 Anon., 'Asian Women subjected to "virginity tests"'.

${ }^{67}$ Parmar, 'Gender, Race and Class', 245. 
${ }^{68}$ Conversation with the artist, 5 August 2017.

${ }^{69}$ Ellicot, 'How the Daily Mail Split Thatcher's Government'.

${ }^{70}$ Evans, 'Margaret Thatcher's shameful support'.

${ }^{71}$ Wilson, Finding our Voice.

72 Mama, 'Black Women', 26.

${ }^{73}$ Parmar, 'Gender, Race, Class', 259.

${ }^{74}$ For useful introduction to the Imperial Typewriters Strike, see https://strikeatimperial.net accessed 15 July 2019.

${ }^{75}$ Wilson, Finding our Voice, 58.

${ }^{76}$ For useful introduction to the Grunwick Strike, see https://www.strikingwomen.org/module/striking-out/grunwick-dispute accessed 18 May 2019.

77 Wilson, Finding our Voice, 54.

${ }^{78}$ Orlando, British Black Art, 100.

${ }^{79}$ Alexander, 'Post-Colonial Theatre of Sense', 5.

${ }^{80}$ Alexander, ibid., 5.

${ }^{81}$ Burman, 'Hiya Sisters', 52.

${ }^{82}$ Conversation with the artist, 5 August 2017.

${ }^{83}$ Burman, cited in Phillips, 'Candy Pop', 5.

${ }^{84}$ Lomax, 'The Politics of Montage', 9.

85 Jones, Body Art, 24.

${ }^{86}$ as cited in Jones, ibid., 24.

${ }^{87}$ Sonia Boyce is another significant British artist using self-portraiture at this time.

See Tawadros, Sonia Boyce.

88 Jones, Body Art, 17.

89 Jones, ibid., 46.

${ }^{90}$ Jones, ibid., 47.

${ }^{91}$ Mercer, 'Romare Bearden', 143.

${ }^{92}$ Burman, cited in Nead, Chila Kumari Burman, 46.

${ }^{93}$ Cho, 'Citizenship', 275.

${ }^{94}$ Cho, ibid., 279.

${ }^{95}$ Burman, 1993, cited in Nead, Chila Kumari Burman, 61-64.

${ }^{96}$ Chambers, Black Artists in Britain, 88.

${ }^{97}$ See Crow, 'Saturday Disasters'.

\section{Bibliography}

A Passage to Britain: Episode Three, The Batory, written and presented by Yasmin Khan; Emily Shields, Executive Producer. A Wall to Wall Production. First broadcast BBC2, 20 September 1918.

Aikens, Nick (ed.), Rasheed Araeen: A Retrospective, Zurich: JRP/ Ringier, 2017. Alexander, Meena, 'Post-Colonial Theatre of Sense: The Art of Chila Kumari Burman, n.paradoxa on-line issue, 14 (2001), 4-13.

Alibhai-Brown, Yasmin, Who Do We Think We Are?: Imagining the New Britain, London: Penguin, 2001.

Anderson, Benedict, Imagined Communities: Reflections on the Origin and Spread of Nationalism, London: Verso, 1991.

Anon., 'Asian Women subjected to "virginity tests" at Heathrow', Telegraph, 9 May 2011, see http://www.telegraph.co.uk/news/uknews/immigration/8501872/Asianwomen-subjected-to-virginity-tests-at-Heathrow.html accessed 26 September 2017. 
Arya, Rina, Chila Kumari Burman: Shakti, Sexuality and Bindi Girls, London: KT Press, 2012, digital publication.

Beckett, Jane, 'Resistance, Continuity, Struggle: The organisers of Along the Lines of Resistance talk to Jane Beckett' Feminist Art News, 2:9, 4-7.

Bhabha, Homi, The Location of Culture, London: Routledge, 1994.

Bhavnani, Kum Kum, 'Racist Acts', Spare Rib, 115 (1982), 49-52.

Biswas, Sutapa; Edge Sarah; and Slattery, Claire, Along the Lines of Resistance: An

Exhibition of Contemporary Feminist Art, Barnsley: Cooper Art Gallery, 1988.

Burman, Chila, 'Hiya Sisters', Spare Rib, 128 (1983), 52-5

Carby, Hazel V., 'White women listen! Black feminism and the boundaries of sisterhood' in The Empire Strikes Back: Race and Racism in 70s Britain, ed. CCCS, 212-235, London: Routledge 1982.

Chambers, Eddie, Black Artists in Britain: A History since the 1950s, London: IB Tauris, 2014.

Cherry, Deborah, 'Suitcase Aesthetics: The Making of Memory in Diaspora Art in Britain in the Later 1980s', Art History, 40:4 (2017), 784-807.

Cho, Lily, 'Citizenship, Diaspora and the Bonds of Affect: The Passport',

Photograph, Photography and Culture, 2: 3 (2009), 275-287.

Crow, Thomas, 'Saturday Disasters: Trace and Reference in Early Warhol', in Modern Art in the Common Culture, London: Yale University Press, 1996, 49-65. Dhondy, Farrukh, 'Legacy of the Raj', Ten:8, 16, 48-53.

Dhondy, Farrukh, 'Asian Communities, Asian Workers and Race Today', in Here to Stay, Here to Fight: A Race Today Anthology, eds. Paul Field, Robin Bunce, Leila Hassan, and Margaret Peacock, 105-140, London: Pluto Press, 2019.

Dummett, Michael, On Immigration and Refugees, London: Routledge, 2002. Ellicot, Claire, 'How the Daily Mail Split Thatcher's Government', MailOnline, 24 August 2916, http://www.dailymail.co.uk/news/article-3755199/Secret-papers-revealrift-Mail-s-campaign-Zola-Budd.html accessed 26 September 2017.

Evans, Gavin, 'Margaret Thatcher's shameful support for apartheid', Mail and Guardian, 19 April 2013, https://mg.co.za/article/2013-04-19-00-margaret-thatchersshameful-support-for-apartheid accessed 26 September 2017.

Fernando, Sonali, 'Chila Kumari Burman', in Beyond Frontiers: Contemporary British Art by Artists of South Asian Descent, ed. Amal Ghosh and Juginder Lamba, 57-63, London: Saffron, 2001.

Jones, Amelia, Body Art: Performing the Subject, Minneapolis: Minnesota University Press, 1998, p.24.

Karimjee, Mumtaz and Patel, Amina, 'Aurat Shakti, Ten.8: The Critical Decade, 2:2 (1992) 42-3.

Kennard, Peter,

Maggie Regina, 1983. Image available at http://www.peterkennard.com/work/\#/newpage-2/ accessed 26 September 2017.

Layton Henry, Zig, The Politics of Race in Britain, Oxford: Blackwell, 1992.

Lomax, Yve, 'The Politics of Montage', Camerawork, 24 (1982), 9.

Mama, Amina, 'Black women, the economic crisis and the British state', Feminist Review: Many Voices, One Chant, Black Feminist Perspectives, 17 (1984), 22-34. Marangoly George, Rosemary, The Politics of Home: Postcolonial Relocations and Twentieth Century Fiction, London: Cambridge University Press, 1996. 
Mercer, Kobena, 'Romare Bearden 1964 Collage as Kunstwollen', in Cosmopolitan Modernisms, ed. Kobena Mercer, 124-145, London: Institute of International Visual Arts (inIVA), 2005.

Nead, Lynda, Chila Kumari Burman: Beyond Two Cultures, London: Kala Press, 1995.

O'Byrne, Darren J. 'On Passports and Border Controls', Annals of Tourism Research, 28: 2 (2001), 399-416.

Orlando, Sophie, British Black Art: Debates on Western Art History, Paris: Éditions dis Voir, 2016.

Owens, Craig, 'Representation, Appropriation and Power', in Representation, Power and Culture, eds. S. Bryson, B. Kruger, L. Tillman, and J. Weinstock, 88-113, University of California Press, 1992.

Parker, Rozsika and Pollock, Griselda, eds., Framing Feminism: Art and the Women's Movement 1970-85, London: Pandora, p.64.

Parmar, Pratibha, 'Black Feminism: The Politics of Articulation', in Identity: Community, Culture, Difference, ed. Jonathan Rutherford, 101-126, London: Lawrence \& Wishart, 1991.

Parmar, Pratibha, 'Gender, Race and Class: Asian Women in Resistance', in The Empire Strikes Back: Race and Racism in 70s Britain, ed. CCCS, 236-275, London: Routledge 1982.

Perez, Nina, 'Chila Kumari Burman: Horizon Gallery', Feminist Art News, 3: 6, 3031.

Phillips, John, 'Candy Pop and Juicy Lucy: Voices beneath the surface of collage', in Chila Kumari Burman: Candy Pop and Juicy Lucy, 4-7, London: Stephen Lawrence Gallery, 2006.

Piper, Keith, 'Body \& Text', Third Text, 2 (1987/88), 53-62.

Poovaya Smith, Nima, The Circular Dance, Bristol: Arnolfini, 1992.

Powell, Enoch, 'Address to Conservative Association meeting', Birmingham, 20 April 1968. Full text of the speech is available at http://www.telegraph.co.uk/comment/3643823/Enoch-Powells-Rivers-of-Bloodspeech.html, accessed 26 September 2017.

Samuel, Raphael, Island Stories: Unveiling Britain: Theatres of Memory, Volume II, London: Verso, 1998, p.330.

Sharma, Ashwani, 'Said Adrus's Zeitgeist, Chila Kumari Burman's Convenience Not Love and Pratibha Parmar's Sari Red', in The Place is Here: The Work of Black Artists in 1980s Britain, eds. Nick Aikens and Elizabeth Robles, 323-347, Berlin: Sternberg Press, 2019.

Sivanandan, Ambalavaner, 'Catching History on the Wing', speech given at Institute of Race Relations Fiftieth Celebration Conference, 1 November 2008, available at http://www.irr.org.uk/news/catching-history-on-the-wing, accessed 26 September 2017.

Smith, Evan and Marmo, Marinella, 'Uncovering the "virginity testing" controversy in the National Archives: the intersectionality of discrimination in British immigration history', Gender \& History, 23: 1 (2011), 147-165.

Solomos, John, Findlay, Bob, Jones, Simon and Gilroy, Paul, 'The Organic Crisis of British capitalism and race: the experience of the Seventies', in The Empire Strikes Back: Race and Racism in 70s Britain, ed. CCCS, 9-46, London: Routledge, 1982. Spencer, Ian R G., British Immigration Policy Since 1939: The Making of MultiRacial Britain, London: Routledge, 1997. 
Tawadros, Gilane Sonia Boyce: Speaking in Tongues, London: Kala Press, 1997. Taylor, Miles 'Bull, John (supp. fl. 1712-)', Oxford Dictionary of National Biography, Oxford University Press, 2004; online edn, May 2006 [http://www.oxforddnb.com/view/article/68195, accessed 19 Sept 2017] Thatcher, Margaret, World In Action, 27 January 1978, full transcript available at http://www.margaretthatcher.org/document/103485 accessed 26 September 2017. The Medium and the Message: Five Woman Printmakers, Rochdale Art Gallery, 1988, unpaginated

Torpey, John, The Invention of the Passport: Surveillance, Citizenship and the State, Cambridge: Cambridge University Press, 2000.

Trivedi, Parita, 'To Deny Our Fullness: Asian Women in the Making of History', Feminist Review: Many Voices, One Chant, Black Feminist Perspectives, 17 (1984), 37-50.

Visram, Rozina, Ayahs, Lascars and Princes: Indians in Britain, 1700-1947, London: Pluto Press, 1986.

Viyas Mongia, Radhika, 'Race, Nationality, Mobility: A History of the Passport', in.), After the Imperial Turn: Thinking With and Through the Nation, ed. Antoinette Burton, 196-214, Durham, NC: Duke University Press, 2003.

Webster, Wendy, 'The Empire Comes Home: Commonwealth Migration to Britain' in.), Britain's Experience of Empire in the Twentieth Century, ed. Andrew Thompson, 122-160, Oxford: Oxford University Press, 2012.

Wheeler, Caroline and Tominey, Camilla, 'Britain's Blue Passport RETURNS', Express, 3 April 2017, http://www.express.co.uk/news/uk/786788/brexit-passportdesign-uk-dark-blue-home-office-project-eu-article-50 accessed 26 September 2017. Wilson, Amrit, Finding a Voice: Asian Women in Britain, London: Virago, 1978. 